\title{
Developing Students' Worksheets "Kikimashou” to Assist Students in an Independent Listening Class
}

\author{
Rusmiyati \\ Universitas Negeri Surabaya \\ Indonesia \\ rusmiyati@unesa.ac.id
}

\author{
Nise Samudra Sasanti \\ Universitas negeri Surabaya \\ Indonesia \\ nisesamudra@unesa.ac.id
}

\begin{abstract}
This developmental research concerning student's worksheets or Lembar Kerja Mahasiswa (LKM) 'Kikimashou' was conducted on case of students' passivity in class, in which the electronic materials were given previously. Students' difficulties included the lack of vocabulary and contents knowledge of the material which have fast intonation of speech that reduced the students' motivation in learning activities. In addition, the focus of the students was occasionally interrupted during the listening practices, either in class or while self-study at home. Therefore, an LKM is needed to assist the students in gathering the small information from the material. In return, it is expected that it indirectly will help them to study independently at home. The LKM was developed from the book 'Mainichi no Kikitori 50 Nichi Jo' and 'Mainichi no Kikitori 50 Nichi Ge'. Of the 50 themes, only 10 themes were taken and developed. This research and development was conducted at level 1 (low level of $R \& D$ level) with the focus on doing research without making and testing the actual product in real life situations. The output of this study is the draft of LKM 'Kikimashou' validated only internally, and is not going into production or validated externally. Nevertheless, a small-scale test with only 2 themes was undertaken for this project.
\end{abstract}

Keywords-student Worksheets

\section{INTRODUCTION}

There are four language skills stundets have to master; speaking, reading, writing, and listening. Listening learning in Japanese Education Department is accommodated in Chokai course. The course can be taken when students are in the third semester (Chukyu Chokai) and $4^{\text {th }}$ (Chujokyu Chokai), in which they further continue into a higher course named Jokyu Chokai in the fifth semester. For those who were enrolled in 2015, Chujokyu Chokai course with two credits can be programmed in 2016-2017 education period which is conducted once a week.

The materials in Chujokyu Chokai course are from books entitled Mainichi no Kikitori 50 Nichi Jo [1] and Mainichi no Kikitori $50 \mathrm{Nichi}$ Ge [2]. The books covered 50 themes for teaching and learning process which are packed in a form of discussion and news information delivered with a bit faster intonation. Soft file of the books were used as the preparation for the upcoming learning process in the classroom.
According to the researchers' initial observation done to those enrolled in 2016-2017 periods in Chukyu Chokai class, students were still passive eventhough the soft file materials had been given before the meetings were conducted. Surprisingly, many students also did not know the materials discussed for the following days. The teachers already used cooperative learning such as Student Teams Achievement Division (STAD) to engage with the students, but the students still showed low level of interest. Because of that, the teachers needed to give initiations to make students more active. Meanwhile, the materials were too difficult due to the complex grammatical structure and fast speaking intonation. Based on the interviews conducted to five students, the learning difficulties in listening class were: (1) limited vocabulary mastery, (2) content difficulty, and (3) fast speaking intonation that led to students' unmotivated will in learning. In addition, students did not focus on the learning activities either in class or at home. Therefore, the researchers argued that developing student's worksheet was vital to assist student do independent or autonomous learning. Based on the completed questionnaire given to the students, results showed that students need a worksheet to help them conceptualize what contained in listening materials.

Referring to the students' needs, the researchers then develop students' worksheet titled "Kikimashou from books entitled Mainichi no Kikitori 50 Nichi Jo" and "Mainichi no Kikitori $50 \mathrm{Nichi}$ Ge". These worksheets focuses on listening exercises aimed to help, guide, and conceptualize the listening contents. The worksheet also contained additional information regarding Japanese cultures that cope with every different theme to accelerate student's Japanese-related knowledge. However, only a few of selected themes contained in the books were used to develop the worksheet. The researhcers only develop the initial level of $\mathrm{R}$ and $\mathrm{D}$ model, in which they only conduct a research without creating the product, or as so-called field study [3]. It means that this study only created an initial draft of Kikimashou that was validated internally. However, this study did a trial in a limited scope, i.e. testing one to two themes only. The full theme trial will be done in near future to the next enrolled students for Chokai course.

Similar study previously conducted a development of book called "Kana Dekiru" that was used in enhancing beginner Japanese learners' skills of mastering Hiragana and Katakana alphabets. The developed book was in a form of students' 
worksheet which was similar to the present study. The difference laid on the fact that this present study aimed at improving listening skill toward Japanese conversation or dialogue.

\section{A. Definition of Student's Worksheet}

Student's worksheet often refers to a set of activities for students practice the learned materials. However, student's worksheet used in this study titled "Kikimashou" is only for college students. The worksheet becomes one of learning sources and media containing assignments for listening materials relevantly to basic competence, which were developed regarding the learning objectives of Chokai course. Moreover, the worksheet is also known as teaching materials covering information, tools, or texts arranged systematically which portray the whole competences students need to master and use in regard to planning and analyzing learning objectives[4]. The examples of teaching materials include text book, module, handout, student's worksheet, audio, and other interactive modes. Meanwhile, students' worksheet includes any printed media such as books and other visual forms.

\section{B. The Function and Objective of Student's Worksheet}

Prastowo[4] argues that students' worksheet functions as a teaching material that can minimalize students' roles. However, it may boost students' activity in helping them comprehending the learnt materials. It is also able to train students and ease them in following the whole teaching and learning process. Moreover, the objectives lay on the serve of easy teaching materials to interact with the given materials, train students' independence, and ease teachers in giving students' assignments [4].

In line with Prastowo's concept, Achmadi in Nurdin [5] also argued concerning the objective of students' worksheet, mentioned as follows:

a. Making students actively involved in teaching and learning process

b. Helping students develop a concept

c. Training students to find and develop process skills

d. Acting as teacher's and student's reference in conducting teaching and learning process

e. Helping students get information related to learned concept through systematic teaching and learning process

f. Helping students get particular notes learned in teaching and learning process.

In regard to this study, the function and objective is relevant to the rationale in developing the student's worksheet titled Kikimashou which is to help students direct and conceptualize learning materials in Chokai class, and to help students more concentrating on autonomous listening practices.

\section{Types of Student's Worksheet Based on Its Functions}

Student's worksheet was developed based on learning objectives employed within a teaching and learning process. Prastowo [4] mentions the following types:

a. Student's worksheet that helps students find a concept regarding what students have to do, including but not limited to observing and analyzing

b. Student's worksheet that helps students apply and interact with various found concepts.

c. Student's worksheet that functions as a learning guidance containing multi exercises and as a help for memorization and understanding materials in a text book.

d. Student's worksheet that functions as an enforcement given after the students learn a specific topic which emphasizes on deepening materials.

Meanwhile, the development of Kikimashou is aimed at guiding students to understand listening materials, of which the worksheet consists of some questions.

\section{Requirements in Developing Student's Worksheet}

The following aspects are several reqirements in developing student's worksheet:

a. The sentence and word structures should be clear, simple, and easily understood. The new terms are introduced first.

b. Pictures and ilustrations should help students understand learning materials, think critically, and determine variables that will be solved in teaching and leanring process.

c. The format and style should help students guide the logical and systematic order of learning activities, show every part that has been learned, and give impressive design.

Developing students' worksheet should also consider didactic, construction, and technical aspects [5], such as:

a. Didactic aspect should be in line with the principle of effective teaching and learning activity and applicable for wide range of student's intelligence. This aspect aims at developing teacher's characters, including social, emotional, moral and self-aesthetic factors.

b. Construction aspect relates to the use of language, sentence structure, vocabulary, level of difficulty, and clarity.

c. Technical aspect relates to text, picture, and presentation. The used text should consider the font size and be proportional with any attached pictures. In addition, the pictures should represent the contents.

The three requirements above were used in developing Kikimashou to learn listening. Japanese is used to be the language for the whole content. Prastowo [4] denotes several conditions to design student's worksheet, such follows: 
a. Using A4 paper format

b. Numbers of pages

c. Numbering

d. Clarity of materials and instructions that can be understood and readable

This study encompasses the instructions and examples to deal with the questions. The format used in Kikimashou uses A4 paper format with double spacing. The amount of questions depends on the difficulty level of materials.

\section{MethodS}

This R and D model was only limited to Level 1 which was only upto developing an initial draft of Kikimashou. In this condition, the researchers conducted a study to know the potential and problem in an object, to design product, and to examine the product internally [3]. The method used in this study referred to Sugiyono [3]. The product was only validated internally and not tested externally. Three students were asked to give their perspectives on the readability of Kikimashou. The following procedures show how the development of Kikimashou was conducted:

\section{Potential and Problem}

A questionnaire was used to reveal problems occurred in Chokai class. Students enrolled in Chokai class were asked to respond the distributed questionnaire.

2. Information Collection

Students were given a questionnaire to identify the difficult questions in Kikimashou as a reference to make better worksheet.

\section{Product Design}

Designing Kikimashou was conducted by considering didactic requirements which were constructive and technical.

\section{Design Validation}

The validation of the initial Kikimashou draft was done internally by lecturers in Japanese Education.

5. Trial

The validated draft of Kikimashou was then being trialed to two students to know the readability.

In this study, students majoring Japanese Education were employed as the population, while there were 60 students who enrolled in the second year of study times chosen as the sample of the study.

The data needed in this developmental research were qualitative. The data were collected using a questionnaire given to 60 students who were in Chokai course. Then, another questionnaire was used to reveal which materials stated in the used sources were difficult. The sources included Mainichi no Kikitori 50 Nichi Jo [1] and Mainichi no Kikitori 50 Nichi Ge [2].
The research instrument is a measure to reveal either natural or social phenomena (Sugiyono, 2011:148). The instrument used in this study to investigate students' problems in Chokai course was unstructured interview. There were five students who were interview. Data collection technique is an effort to get desired data (Sugiyono, 2011:193). This stage was done before data analysis covering collecting, sorting and classifying data. This study got the desired data using questionnaire and conducting interview to certain students. The obtained data were then analyzed using descriptive qualitative approach.

\section{RESULT AND DISCUSSION}

The procedures of developing Kikimashou were in line with Sugiyono's developmental theory [3]. Meanwhile, the writing formatting used to construct Kikimashou referred to the writing format proposed by Depdikbud. The following describtions were the steps in developing Kikimashou student's worksheet:

\section{A. Potential and Problem}

Students involved in this study were those registered active in Japanese Education Department, especially in Chokai course (listening course) intermediate level (Chukyu) conducted in the third and fourth semesters. In the first and second semester, students also learn listening, but limited to vocabulary and simple dialogue. This was due to the fact that, in the first year, students were exposed to numerous Japanese vocabularies and basic grammar. Meaanwhile, in the second year, they were put in a more complex language structure.

Chokai learning process was conducted in 15 meetings. The materials included short dialogue and simple information about daily life, school life, Japanese culture, scheduling events, and news, of which all contents were wrapped in a form of MP3. Chokai course was given in the first year of study times to make students ready to meet further more complex materials.

With Chokai materials given at the beginning, if there was an unintelligible vocabulary, students could search in the dictionary themselves or asked their friends. But in the real learning process, many students were not ready with the lecture materials discussed on that day. When the teacher asked, almost $70 \%$ students had not opened the materials even though had been previously received. This was also confirmed by the results of interviews and questionnaires distributed by lecturers to students that, in fact, students were rarely trained to listen at home. Many of them were listening to chokai material while studying other subjects. So, this was considered to make them less focused. In addition, the intonation of the conversations tent to be faster and more diverse. The complex grammar made students difficult in capturing the vocabulary and the intended meaning of the conversation. This also made the students passive and quiet. Therefore, the teacher as the researcher wished to assist the student in learning to listen at home as a way of preparing themselves in the next course using the student's worksheet.

With the student worksheet containing the task sheets of the listening material, it was expected to help the students in 
coupling verbatim (goi), connecting with verbs to be sentences then into a unified paragraph entity so that it could be known the meaning. Based on questionnaire results, students were also eager to have media or sheets that helped them direct to understand the content of the materials.

Based on the background above, the researchers intended to develop a student's worksheet called "Kikimashou" to assist students in practicing and learning to listen independently.

\section{B. Information Collection}

The chokai materials were taken from the book Mainichi no Kikitori 50 Nichi Jo and Mainichi no Kikitori 50 Nichi Ge. As parts to make exercises or questions in the student worksheet "Kikimasho", the researcher used a research instrument in the form of a questionnaire, distributing it to the chosen students containing the identification of the most difficult theme. Students were asked to listen to the 50 themes in both books and rank them from the most difficult theme to the easiest theme to understand. Results identified the most difficult themes including Tatameu, Matsu jikan Mataseru Jikan, Shindo, Doraiai, Bento no hi, Konbini Toshokan, Me ni Yasashi Iro, Awadori, Donna Kekkon Hiroen ga ii, and Tsuwa o yameta Wakamono.

\section{PRODUCT DESIGN}

The next developing step after being identified the most difficult theme was to design Kikimashou. In accordance with the original plan specification, the worksheet was made using A4 paper spaced 2 spaces because Japanese characters (Kana and Kanji) required more spaces for students to write answers. Various levels of difficulty problems that were made also depended on the difficulty level of the theme. This "Kikimashou" worksheet referred to the Curriculum of Japanese Education Study Program for Chujokyu Chokai (Chokai advanced) course.

Here are the outline drafts of Kikimashou: Cover page, introduction page, fist theme, instruction, exercises theme 1, second theme, instruction, exercises theme 2, and similarly happened upto the tenth theme. Below is the detail how Kikimashou looks.

\section{a. Kikimashou cover}

\section{問題集}

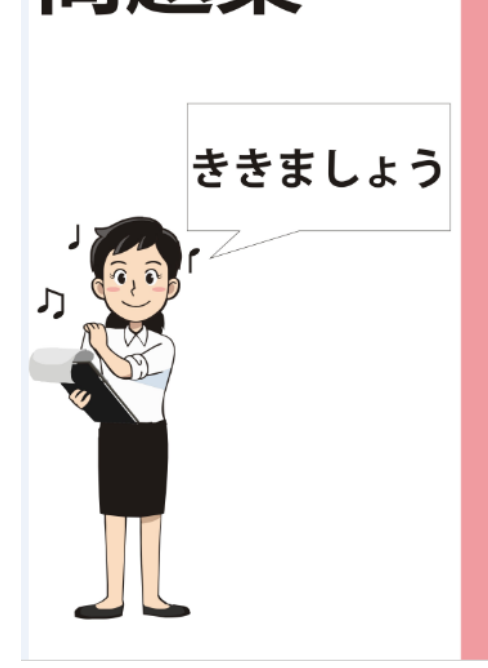

b. Title and question of theme 1: Tatameru Piano

\section{1. たためるビア}

千

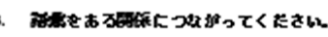

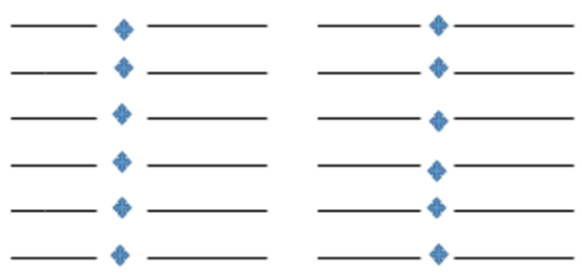


c. Theme 3 : Shindo 3
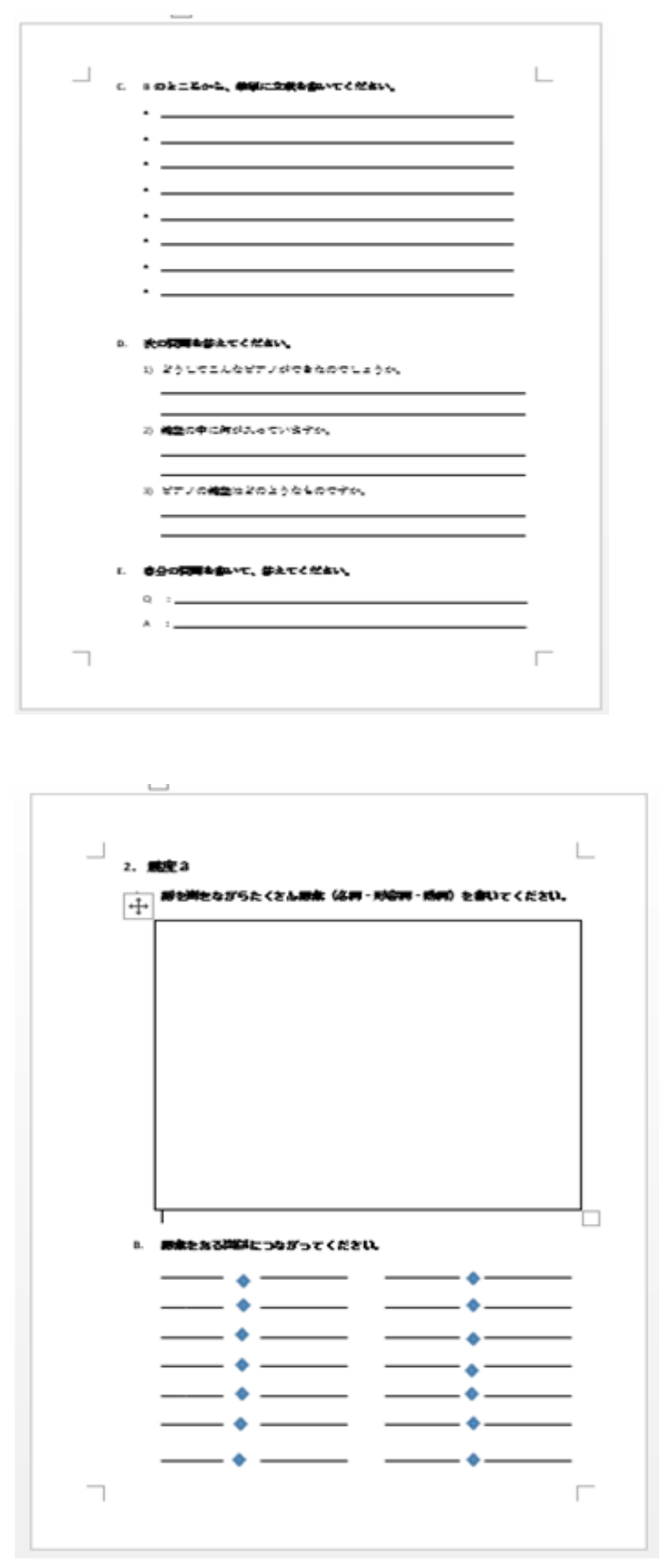

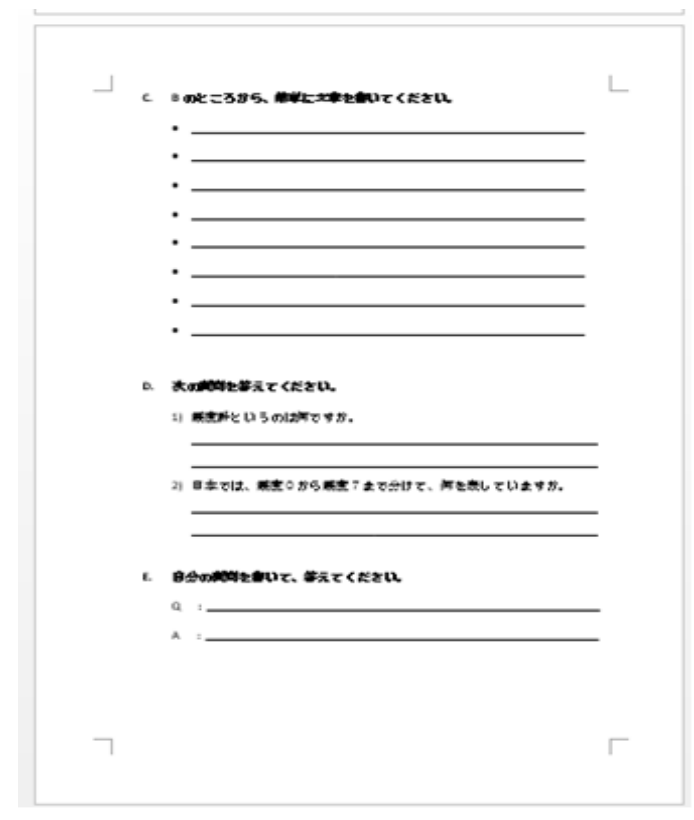

\section{DESIGN VALIDATION}

After the design of the Kikimashou was completed, the next step was Design Validation conducted by an expert or internal practitioner. The internal experts here were senior lecturers who have been an expert in the field of Japanese Language since years. The design validation was carried out by two experts: one lecturer in Japanese Language Education Program and one by Japanese native speaker. However, because of his business, then the validation was done by one lecturer only. As for the better development of Kikimashou, it was suggested to conduct next development research.

Instruments used to determine the feasibility level of Kikimashou was in the form of a questionnaire. Based on the assessment of an expert or Japanese language expert at the internal level of the Japanese Language Study Prodi, the Kikimashou student's worksheet was known as follows:

\begin{tabular}{|l|l|l|l|l|l|}
\hline No & Aspects & $\begin{array}{l}\text { Very } \\
\text { Good } \\
(\mathbf{4})\end{array}$ & $\begin{array}{l}\text { Good } \\
\mathbf{( 3 )}\end{array}$ & $\begin{array}{l}\text { Fair } \\
\mathbf{( 2 )}\end{array}$ & $\begin{array}{l}\text { Bad } \\
\mathbf{( 1 )}\end{array}$ \\
\hline 1 & Design & & & & \\
\hline & Layout & & V & & \\
\hline & Numbering & V & & & \\
\hline & Clear Instruction & & V & & \\
\hline & Readability between & V & & & \\
\hline 2 & Contents & & V & & \\
\hline & $\begin{array}{l}\text { Relevance } \\
\text { contents and theme }\end{array}$ & & & & \\
\hline & Material difficulty & & V & & \\
\hline & Sequential points & & V & & \\
\hline $\begin{array}{l}\text { Difficulty level of } \\
\text { questions }\end{array}$ & & & V & \\
\hline Total & $\mathbf{8}$ & $\mathbf{1 5}$ & $\mathbf{2}$ & $\mathbf{0}$ \\
\hline
\end{tabular}


- The total overall assessment given by the lecturer (experts) from the internal Japanese Language Study Program could be calculated by the following formula: scores

Student's Worksheet score $=$ scores from expert: Total

$$
\begin{array}{cc}
8+15+2 & =25=78 \\
32 & 32
\end{array}
$$

Based on the internal validation, the validation score was 78. This indicates that the Kikimashou was eligible for autonomous learning, and was expected to assist students in listening to materials that had been given by the lecturer, helped direct and conceptualize the material contents which were listened to in accordance with the initial purpose of this worksheet development.

\section{TRIAL}

Kikimashou student's worksheet was then internally trialed to two students. Only two themes had been trialed namely Tatameru Piano and Shindo 3. Then, the two students were interviewed to find out the extent of their understanding in answering the questions. As a result, students admitted that they understood how to answer the questions in Kikimashou and Kikimashou helped them to focus on listening. Moreover, the items were arranged coherently from the smallest part to the most complex exercises to make their own questions in Japanese.

\section{CONCLUSION}

This development study of student's worksheet entitled Kikimashou adapts to Sugiono's development theory which is still at a low level or level 1, where researchers do not develop the product, only collecting opinions from internal expert at Japanese Education Study Program. The development process begins from the problems that arise in learning Chokai or listening to the Japanese language and the need of student's worksheet to help students learn listening materials. Then, the data of the difficult materials are identified through the use of a questionnaire. Thereafter, the worksheet design scheme is established by referring to dicdactic, constructive and technical requirements. Afterwards, the design is internally validated by lecturer at Japanese Language Education Study. Results show that the Kikimashou is eligible to be used in learning listening and helping students learn to listen independently at home.

\section{REFERENCES}

[1] M. Akiko, Chukyu Nihongo Onseikyozai Atarashii Mainichi no kikitori 50 Nichi Jo. Japan: Bonjinsha, 2014.

[2] M. Akiko, 2014. Chukyu Nihongo Onseikyozai Atarashii Mainichi no kikitori 50 Nichi Ge. Japan: Bonjinsha, 2014.

[3] Sugiyono, Metode Penelitian Kuantitatif, Kualitatif, dan R\&D. Bandung: Alfabeta, 2011.

[4] A. Prastowo, 2012. Panduan Kreatif membuat bahan Ajar Inovatif. Jogjakarta: Diva Press, 2012.

[5] S. Nurdin and Adriantoni, Kurikulum dan Pembelajaran. Jakarta: PT. Raja Grafindo, 2016. 